\title{
Isolation of Sango viruses from Israeli symptomatic cattle
}

\author{
Natalia Golender ${ }^{1 *}$, Velizar Bumbarov ${ }^{1}$, Avi Eldar ${ }^{1}$, Lior \\ Zamir $^{2}$, Boris Even Tov², Gabriel Kenigswald ${ }^{3}$ and Eitan \\ Tiomkin $^{3}$
}

${ }^{1}$ Department of Virology, Kimron Veterinary Institute, Beit Dagan, Israel

${ }^{2}$ Israeli Veterinary Services, Rosh Pina, Israel

${ }^{3}$ Hachaklait Veterinary Services, Caesarea, Israel

Received: 29 June, 2021

Accepted: 19 July, 2021

Published: 20 July, 2021

*Corresponding author: Natalia Golender, Department of Virology, Kimron Veterinary Institute, Beit Dagan, Israel, Tel: (+972-9681949); Fax: 972-39681788;

E-mail: golendern@moag.gov.il

ORCID: https://orcid.org/0000-0002-9074-7989

https://www.peertechzpublications.com

Check for updates

\begin{abstract}
Sango Virus (SANV) is a member of the Simbu serogroup within the order Bunyavirales, family Peribunyaviridae, genus Orthobunyavirus. In the end of October, 2019, two SANV virus were identified and isolated from sera sampled from two symptomatic cows, which manifested fever, milk reduction and diarrhea. Two viruses were isolated in Vero cells. Full genome sequencing of these virus isolates was performed. Genetic and phylogenetic analyses of Israeli SANV strains showed their very close relationship. However, they have significant difference in all three genome segments with a sole known isolated Nigerian SANV Ib An 5077 strain.
\end{abstract}

\section{Introduction}

Sango Virus (SANV) is a member of the Simbu serogroup within the order Bunyavirales, family Peribunyaviridae, genus Orthobunyavirus [1]. The only available SANV Ib An 5077 strain was isolated between 1964-1969 in Ibidan, Nigeria from Culocoides spp. [2]. In general, orthobunyaviruses are negativesense RNA viruses, mostly transmitted by mosquitoes or culicoid flies [3]. The genome of orthobunyaviruses comprises three unique segments of single stranded RNA. The average size of each genome segment is of orthobunyaviruses is about $6.9 \mathrm{~kb}$ for the large (L) segment, $4.5 \mathrm{~kb}$ for the medium (M) segment and $1.0 \mathrm{~kb}$ for the small (S) segment [3]. The S segment encodes the nucleoprotein ( $\mathrm{N}$ protein), and non-structural protein (NSs), the M segment encodes polyprotein precursor that yields the two external glycoproteins $\mathrm{Gn}$ and $\mathrm{Gc}$, and the $\mathrm{L}$ segment encodes the RNA-dependent RNA polymerase (RdRp) $[3,4]$.

Veterinary important representatives of the Simbu serogroup are Akabane (AKAV), Schmallenberg (SBV) and Shuni (SHUV) viruses among others, when two of them - SHUV and AKAV, are endemic in Israel [5]. These viruses are also transmitted by insect vectors (mostly by Culicoides biting midges), are distributed worldwide and are known to cause pregnancy abnormalities and severe fetal malformation summarized under the term "arthrogryposis-hydranencephaly syndrome" $[1,6]$. Simbu serogroup virus infections can cause two different types of clinical manifestation in ruminants. Acute infections of animals of all age groups are either asymptomatic or mild, associated with unspecific signs like fever, diarrhea or loss in milk yield for a few days, as was seen with Schmallenberg viral infection of domestic ruminants. However, when naïve dams are infected during a critical phase of gestation, severe congenital defects can occur $[7,8]$. Moreover, AKAV and SHUV can cause neurological diseases and fatalities in affected animals $[9,10]$, when SHUV were detected by molecular methods in several human cases of neurological disease in South African hospital patients [11]. Infected with simbuviruses ruminants usually develop short viremia lasting 2-7 days $[12,13]$.

SANV was probably identified in ruminants only once: in spleen of a springbok, South Africa, which afterwards probably died (the signed sample for investigation was spleen. The phylogenetic tree illustrated relationship with the SANV Ib An 5077 strain by S segment only) [14]. Up today no clinical 
disease has been registered in domestic ruminants caused by SANV. The aim of this study is description of clinical signs in affected cattle and genetic and phylogenetic analyses of the novel SANV Israeli strains.

\section{Materials and methods}

\section{Field samples}

During 2019, a total of 230 plasma, whole blood or serum samples from young and adult sick animals, which were sent to Kimron Veterinary Institute, Beit Dagan, Israel (KVI) for diagnosis of arboviral infections, were tested for simbuviruses (181 sample from cattle, 47- from sheep, and 2 samples from goat).

\section{RNA extraction and qRT-PCR Tests}

Viral RNA was extracted using the MagMAX ${ }^{\mathrm{TM}}$ CORE Nucleic Acid Purification Kit (Thermo Fisher Scientific). All samples were tested for Bovine Ephemeral Fever Virus (BEFV), Epizootic Hemorrhagic Disease Viruses (EHDV), Bluetongue Viruses (BTV) and Simbu serogroup viruses. Thus, for detection of BEFV a method described by Erster was used [15]. EHDV RNA presence was assessed with an Epizootic Hemorrhagic Disease Virus Real-Time PCR Kit (LSI VetMAX, Lissieu, France), according to the instructions of the manufacturer, when BTV RNA presence was assessed with a BTV VetMAX ${ }^{\mathrm{TM}}$ BTV NS3 All Genotypes Kit (Applied Biosystems ${ }^{\mathrm{TM}}$, Thermo Fisher Scientific Inc., France) qRT-PCR was applied for detection of simbuviruses according to Golender, et al. [5].

\section{Virus identification}

At first stage virus identification was done by partial sequencing of the $\mathrm{S}$-segment using the same pair of primers as used for simbuvirus detection [5]. For precise virus identification the universal primers for $M$ segment 388 bp fragment enable for detection of both SANV and Peaton (PEAV) viruses were developed (PEAV-M-94F '5- AAA AGG TGG RAA GTG CTT TTA T-3' and PEAV-M-458R '5- CCA TTT TTT ATT GTA GTT CCT TG-3').

\section{Sequencing, BLAST and phylogenetic analyses}

For conventional RT-PCRs the One-Step RT-PCR kit (Qiagen, Hilden, Germany) was used. The complete sequences of all three viral segments were obtained by Sanger sequencing using overlapping pairs of primers (available by request). The cDNA fragments were purified with the MEGAquick-spin Total Fragment DNA Purification Kit (iNtRON Biotechnology, Gyeonggi-do, South Korea) and subsequently sequenced by standard Sanger methods in both directions using an ABI 3730xl DNA Analyzer (Hylabs, Rehovot, Israel). The resulting nucleotide sequences were assembled and nucleotide (nt) sequences were aligned and pairwise compared by using Geneious version 9.0.5 (Biomatters, Auckland, New Zealand). Phylogenetic trees were constructed using the Mega X software [16].

\section{Virus isolation}

African green monkey kidney cells (Vero) were applied as described previously [17]. In brief, monolayer Vero cells were inoculated with sera samples and examined daily for evidence of cytopathic effect (CPE). Two passages were performed. The cells, which were infected with field samples (sera), were frozen at $-80^{\circ} \mathrm{C}$ after 5 days of incubation. The full CPE was observed in both cases at $2^{\text {nd }}$ passage on day 3 after infection.

\section{Results}

\section{Clinical signs}

Whole blood and sera samples from three fattening cows (Moshav Ma'ale Gamla, the Golan Heights, October 27, 2019) and the same kind of samples from five milking cows (Moshav Kanaf, the Golan Heights October 30, 2019) were sent to KVI. Sick cows demonstrated fever, hypersalivation, milk reduction and diarrhea. Two specific adult cows (one- age was unknown, the second- 7 years-old cow), which were found viremic for simbuviruses, manifested fever, milk reduction and diarrhea. The 7 years-old cow was soon slaughtered because of bad improvement in body condition and milk production after the disease. Notably, the only single sample was identified as positive for SHUV samples from all other samples, which were sent during 2019 from symptomatic adult and young domestic ruminants: from an adult cow shortly after abortion from Moshav Ma'ale Gamla, which blood was sampled at July, 2, 2019.

\section{qRT-PCR results}

Blood samples collected from three sick cows from Moshav Ma'ale Gamla, showed that one cow was positive for BTV, one- for simbuviruses, and one was negative in all tests. Blood samples collected from five sick cows from Moshav Kanaf, showed that three cows were positive for BTV, one- for simbuviruses, one was negative in all tests. No mixed infections were identified (full data on BTV is not shown). Pan-Simbu RT-qPCR positive samples showed cycle threshold 22.34 and 17.9.

\section{Virus isolation}

Two strains ISR-2061/3/19 and ISR-2097/1/19 were isolated. CPE was observed on the second passage of both samples. Virus replication was confirmed basing on Pan-Simbu RT-qPCR and sequencing.

\section{Genetic and phylogenetic analyzes}

Partial sequence of $\mathrm{S}$ segment used for identification of the virus [16], showed the same similarity to SANV and Peaton (PEAV) viruses. The universal primers for $M$ segment $388 \mathrm{bp}$ fragment, enable for detection of both SANV and PEAV showed $92.25 \%$ and $92.19 \%$ of nucleotide (nt) identity to SANV IbAn 5077 strain following by Australian PEAV cs322 strain with $86.86-86.75 \%$ of nt identity.

The complete sequences of ISR-2061/3/19 and ISR2097/1/19 strains have been deposited in GenBank under accession numbers MZ285919 - MZ285921 and MZ285922 MZ285924, respectively.

BLASTn and phylogenetic analysis showed belongings of Israeli strains to SANV by all three segments (Figure 1). Both 


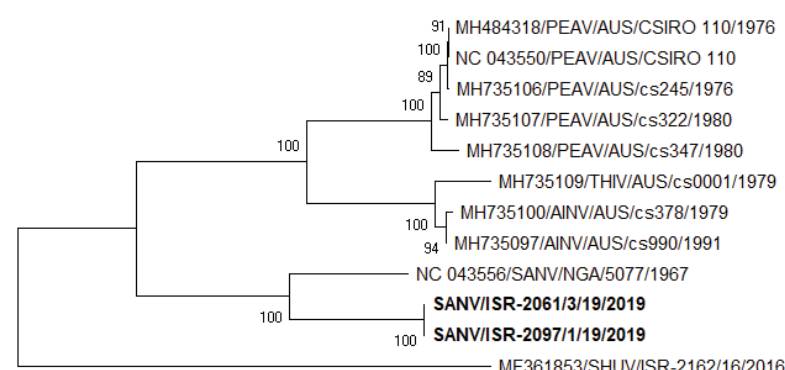

0.050

a) $L$ segment

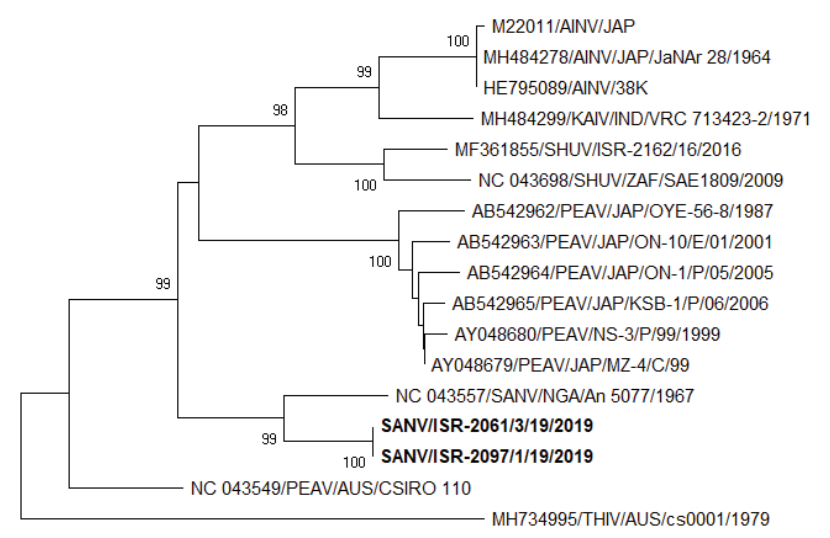

0.020

b) S segment

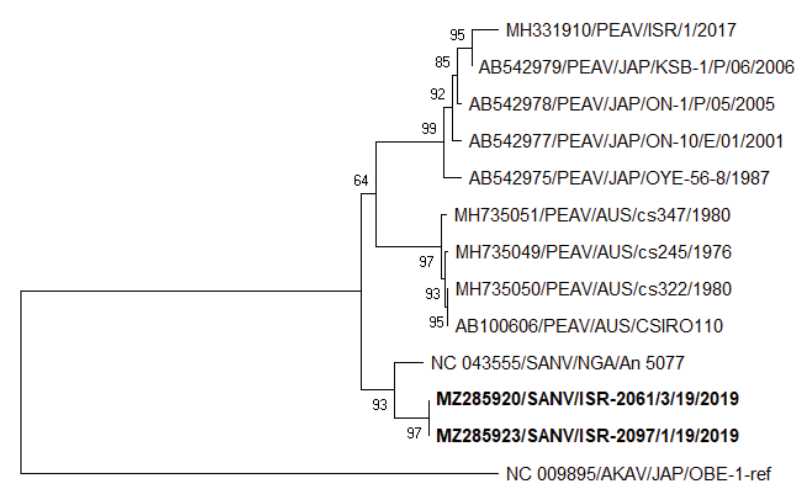

0.1

c) M segment

Figure 1: Phylogenetic analysis of Israeli Sango viruses (SANV) based on nucleotide sequences of the $L(a), S$ (b) and $M(c)$ segments and their comparison to other related simbuviruses. The evolutionary history was inferred using the NeighborJoining method. The percentage of replicate trees in which the associated taxa clustered together in the bootstrap test (1000 replicates) are shown next to the branches. The tree is drawn to scale, with branch lengths in the same units as those of the evolutionary distances used to infer the phylogenetic tree. The evolutionary distances were computed using the Maximum Composite Likelihood method and are in the units of the number of base substitutions per site. All positions containing gaps and missing data were eliminated (complete deletion option). The sequences obtained from NCBI GenBank are labelled by accession number/virus/location/ isolate/year. Sequences generated in the present study are marked by bold fond.

Israeli SANV had identical S segment nt sequences. BLASTn analysis of S segment showed of $96.30 \%$ of nt identity with SANV SANV Ib An 5077 followed by PEAV SCIRO 110 strain with
91,86\% of nt identity. BLASTp analysis indicated $100 \%$ of aa identity by N protein with PEAV SCIRO 110 strain and $95 \%$ identity by NSs proteins with PEAV SCIRO 110 strain. BLASTn analysis of M segment of ISR-2061/3/19 and ISR-2097/1/19 showed of $92,54 \%$ and $92,58 \%$ of nt identity to SANV SANV Ib An 5077 strain following by PEAV KSB-1/P/06 strain with $83,80 \%$ and $83,82 \%$ of $n t$ identity, respectively. BLASTp analysis of polyproteins of ISR-2061/3/19 and ISR-2097/1/19 strains showed $97,21 \%$ and $97,36 \%$ identity to SANV, followed by PEAV ON-1/P/05 strain with $92,07 \%$ and $92,14 \%$ of aa identity, respectively. BLASTn analysis of L segment of ISR2061/3/19 strains showed of $91.91 \%$ of nt identity with SANV SANV Ib An 5077 followed by PEAV SCIRO sc990 strain with $84.61 \%$ of nt identity, when analysis ISR-2097/1/19 strain showed of $91.96 \%$ of nt identity with SANV SANV Ib An 5077 following by PEAV SCIRO sc990 strain with $84.58 \%$ of nt identity. BLASTp analysis of RdRp proteins showed $98,45 \%$ of aa identity to SANV Ib AN 5077 strain and 94,23\% of aa identity to several different PEAVs of both SANV Israeli strains.

\section{Discussion}

Since the first case of SANV isolation in 60-s in Nigeria, SANV was detected one time only in a South African springbok manifesting neurologic signs, which afterwards probably died (the signed sample for investigation was spleen) [14]. Unfortunately, the sequences of this isolate were not published in the GenBank, it is impossible to compare Israeli and South African SANV strains. Identification and isolation of SANV in symptomatic cattle demonstrates ability of additional member of Simbu serogroup to develop mild clinical manifestations of the disease in cattle. As we see in case of SBV infection, it was firstly identified in several European countries as a simbuvirus causing mild manifestation of the disease in cattle [18]. Few months later SBV was identified in aborted and malformed fetuses of domestic ruminants [18]. In spite of the fact that during the next 1,5 year period no cases of SANV were identified neither in aborted fetuses nor in symptomatic animals, further observation after cases of "abortion storms" or neurological cases in cattle have to be done.

\section{Author contributions}

Methodology, N.G.; software, N.G.; investigation, N.G. and V.B.; resources, B.E.T., L.Z., E.T. and G.K.; data curation, V.B.; writing-original draft preparation, N.G.; writing—review and editing, V.B.; supervision, A.E.; funding acquisition, A.E. All authors have read and agreed to the published version of the manuscript.

\section{Acknowledgments}

We thank Ms. Olga Zalesky and Dr. Anita Kovtunenko for technical assistance.

\section{References}

1. Sick F, Beer M, Kampen H, Wernike K (2019) Culicoides Biting MidgesUnderestimated Vectors for Arboviruses of Public Health and Veterinary Importance. Viruses 11: E376. Link: https://bit.ly/3kz0nme

2. Causey OR, Kemp GE, Causey CE, Lee VH (1972) Isolations of Simbu- 
group viruses in Ibadan, Nigeria 1964-69, including the new types Sango, Shamonda, Sabo and Shuni. Ann Trop Med Parasitol 66: 357-362. Link: https://bit.ly/3rwalRr

3. Elliott RM (2014) Orthobunyaviruses: recent genetic and structural insights Nat Rev Microbiol 12: 673-685. Link: https://bit.ly/2TpUBYY

4. Elliott RM, Blakqori G (2011) in Bunyaviridae. Molecular and Cellula Biology; Plyusnin, A.; Elliott, R. M. (eds.) Caister Academic Press. Link: https://bit.ly/3invXR2

5. Golender N, Bumbarov VY, Erster O, Beer M, Khinich Y, et al. (2018) Development and validation of a universal S-segment-based real-time RT-PCR assay for the detection of Simbu serogroup viruses. J Virol Methods 261: 8085. Link: https://bit.ly/3ktE55j

6. Beer M, Wernike $\mathrm{K}$ (2021) Akabane virus and schmallenberg virus (peribunyaviridae). In: Bamford, D.H. and Zuckerman, M. (eds.) Encyclopedia of Virology, 4th Edition, Oxford: Academic Press 2: 34-39.

7. Kirkland PD (2015) Akabane virus infection. Rev Sci Tech 34: 403-410. Link: https://bit.ly/3etVMxx

8. Kono R, Hirata M, Kaji M, Goto Y, Ikeda S, et al. (2008) Bovine epizootic encephalomyelitis caused by Akabane virus in southern Japan. BMC Vet Res 4: 20. Link: https://bit.ly/3wOOevQ

9. Golender N, Bumbarov V, Assis I, Beer M, Khinich Y, et al. (2019) Shuni virus in Israel: Neurological disease and fatalities in cattle. Transbound Emerg Dis 66: 1126-1131. Link: https://bit.ly/3Bspqg0

10. van Eeden C, Williams JH, Gerdes TG, van Wilpe E, Viljoen A, et al. (2012) Shuni virus as cause of neurologic disease in horses. Emerg Infect Dis 18: 318-321. Link: https://bit.ly/3wJCOJT

11. Motlou TP, Venter M (2021) Shuni Virus in Cases of Neurologic Disease in Humans, South Africa. Emerg Infect Dis 27: 565-569. Link: https://bit.ly/3wJczTO

12. Sick F, Breithaupt A, Golender N, Bumbarov V, Beer M, et al. (2020) Shun virus-induced meningoencephalitis after experimental infection of cattle. Transbound Emerg Dis 68: 1531-1540. Link: https://bit.ly/3rjwhnT

13. The Center of Food Sequrity \& Public Health. Link: https://bit.ly/3h04edp

14. Steyn J, Motlou P, van Eeden C, Pretorius M, Stivaktas VI, et al. (2020) Shuni Virus in Wildlife and Nonequine Domestic Animals, South Africa. Emerg Infect Dis 26: 1521-1525. Link: https://bit.ly/3irTn7M

15. Erster O, Stram R, Menasherow S, Rubistein-Giuni M, Sharir B, et al. (2017) High-resolution melting (hrm) for genotyping bovine ephemeral fever virus (befv). Virus Res 229: 1-8. Link: https://bit.ly/3zaeSkm

16. Kumar S, Stecher G, Li M, Knyaz C, Tamura K (2018) MEGA X: Molecular Evolutionary Genetics Analysis across Computing Platforms. Mol Biol Evol 35 1547-1549. Link: https://bit.ly/3BIGCVg

17. Poskin A, Martinelle L, Van der Stede Y, Saegerman C, Cay B, et al. (2017) Genetically stable infectious Schmallenberg virus persists in foetal envelopes of pregnant ewes. J Gen Virol 98: 1630-1635. Link: https://bit.ly/3z75Lkg

18. Wernike K, Beer M (2017) Schmallenberg Virus: A Novel Virus of Veterinary Importance. Adv Virus Res 99: 39-60. Link: https://bit.ly/2VRh1Tz

\section{Discover a bigger Impact and Visibility of your article publication with} Peertechz Publications
Highlights

* Signatory publisher of ORCID

- Signatory Publisher of DORA (San Francisco Declaration on Research Assessment)

- Articles archived in worlds' renowned service providers such as Portico, CNKI, AGRIS, TDNet, Base (Bielefeld University Library), CrossRef, Scilit, J-Gate etc.

* Journals indexed in ICMJE, SHERPA/ROMEO, Google Scholar etc.

* OAI-PMH (Open Archives Initiative Protocol for Metadata Harvesting)

* Dedicated Editorial Board for every journal

* Accurate and rapid peer-review process

* Increased citations of published articles through promotions

* Reduced timeline for article publication

Submit your articles and experience a new surge in publication services (https://www.peertechz.com/submission).

Peertechz journals wishes everlasting success in your every endeavours.

Copyright: (c) 2021 Golender N, et al. This is an open-access article distributed under the terms of the Creative Commons Attribution License, which permits unrestricted use, distribution, and reproduction in any medium, provided the original author and source are credited.

Citation: Golender N, Bumbarov V, Eldar A, Zamir L, Tov BE, et al. (2021) Isolation of Sango viruses from Israeli symptomatic cattle. Int J Vet Sci Res 7(2): 069-072. DOI: https://dx.doi.org/10.17352/ijvsr.000082 